\title{
FERIMENTOS CUTÂNEOS EM HAMSTERS (Mesocricetus auratus) DE CATIVEIRO DOMÉSTICO MÁRCIO CHIQUITO ${ }^{1}$; PAULO ROGÉRIO MANGINI ${ }^{1}$; PEDRO RIBAS WERNER ${ }^{2}$; GUILHERME GONÇALVES ${ }^{3}$; JOSÉ RICARDO PACHALY ${ }^{2}$
}

\author{
${ }^{1}$ Mestrandos do Curso de Pós-Graduação em Ciências Veterinárias da Universidade Federal do Paraná; \\ ${ }^{2}$ Professores da Universidade Paranaense UNIPAR, Umuarama-PR; ${ }^{3}$ Aluno do Curso de Graduação em Medicina \\ Veterinária da Universidade Federal do Paraná.
}

O estudo dos ferimentos em hamsters reveste-se de interesse porque a literatura traz pouquíssima informação sobre essas lesões naquela espécie. Em vista disso, elaborou-se o presente trabalho, primeiro segmento de um estudo amplo sobre a patologia dos hamsters de cativeiro doméstico. Entre maio de 1996 e outubro de 1998, em uma criação doméstica de hamsters em Balsa Nova, PR, registraram-se 32 casos de ferimentos cutâneos de ocorrência natural. Tratava-se de 13 ferimentos perfurantes puntiformes, 4 incisões, 6 lacerações, quatro avulsões, duas contusões e duas feridas perfurocontusas. Os sítios atingidos foram o dorso (seis casos), as orelhas (cinco casos), a face, região lombar e os flancos (quatro casos cada), lábio e nariz (dois casos cada), ventre, pescoço, escroto, dedos, tórax, fronte e pálpebras (um caso cada). As punções e incisões não foram tratadas. Nas avulsões, empregou-se a polivinilpirrolidona iodo tópica. As lacerações foram tratadas experimentalmente com infusão de Tanacetum vulgare, e as contusões com gel de escina sódica, localmente aplicado. O tempo de cura para as punções e incisões foi inferior a sete dias; para as lacerações e avulsões variou de sete a 14 dias, e para as contusões oscilou entre cinco e nove dias. As punções, incisões, lacerações e avulsões resultaram de lutas entre hamsters. As contusões e feridas perfurocontusas foram causadas por mordida de cão ou gato. As feridas perfurocontusas foram encontradas em animais que morreram devido ao ataque. 